\title{
Xperimental Studies on Characterising Of Aseismic Performance of Reinforced Concrete Frames
}

\author{
${ }^{1}$ Prof.R.Ravi, ${ }^{2}$ Prof.Dr.C.Manoharan \\ ${ }^{1}$ Research scholar, Anna University of Technology, coimbatore, Tamilnadu. \\ ${ }^{2}$ Principal, Annai Mathammal Sheela Engineering College, Namakkal, Tamilnadu.
}

\begin{abstract}
A few research works have been carried out for the past two decades, so I took research in advanced side. The basic investigation under dynamic loads starts with the estimation of the natural frequencies of the structure or system under consideration. This is an important parameter under dynamic analysis. Hence a detailed study has been carried out on the influence of un-reinforced masonry infill (masonry infill) on fundamental natural frequency of Reinforced Concrete (RC) frames. Masonry infill though considered as non-structural element largely effect the strength, stiffness and ductility of the framed structure during the application of lateral loads such as wind and earthquake loads. Experimental and numerical studies are carried out on $2 D$ and $3 D$ RC frames under different configurations of masonry infill in addition to bare frames. The RC frames are designed and detailed as per the relevant Indian standard codes. A simple numerical method has been formulated to obtain the natural frequencies of RC frames with masonry infill in the FE analysis. Tri-axial shake table is used for the determination of natural frequencies experimentally. These results are compared with the empirical formulae given in national and international codes for finding the natural frequencies. This research program is a part of the project sanctioned by Ministry of Earth Sciences, Government of India and investigation on $2 D$ frames is carried out at Central Power Research Institute, Bengaluru and at Adhiyamaan College of Engineering, Hosur, focusing on the Response evaluation of $R C$ frames under dynamic loading. This dissertation report consists of design and construction of RC frames, numerical formulation, FE analysis, Shake table tests and comparison of national and international codes.
\end{abstract}

Keywords: RC frames, Natural frequency, Masonry infill, Shake table

\section{Introduction}

Reinforced concrete (RC) frames with Un-Reinforced Masonry Infill panels (Masonry infills) are one of the most famous and most utilized types of construction throughout the world. The major reason for this apart from ease of construction and economy is the fact that masonry infill provides excellent insulation and isolation from climatic forces such as heat, sun, wind, rains, extreme cold etc. Moreover they have a very good fire resistance too. The masonry infills are invariably constructed after the basic framework of beams, columns and slabs have gained sufficient strength. As a result, the bond of masonry infill with the RC framework is negligible at sides and top surface of the wall. Therefore, they are classified as non-structural elements and the structures are analyzed and designed by considering them only as dead mass, while neglecting any kind of structural interaction of such panels. This assumption of neglecting the effects of masonry infill is reasonable and justifiable for the structure under gravity loads. However, the same is not true for the structures with masonry infills when subjected to lateral loads, especially seismic loads. Under seismic loads, the stiffness additions due to masonry infills modify the behavior of structure significantly by altering its frequency. Many National and International Standards have recommended different empirical formulations to tackle the above problem, dividing it into two parts (i) Bare framed structure and (ii) Framed structures with masonry infills. They do not give due consideration to the location and percentage of infills in the structure. Extensive researches have been carried out worldwide in the last five decades. Many methods have been developed for the dynamic analysis of RC frames with masonry infills incorporating one or more simplifying assumptions regarding its stiffness. This research is one such attempt to address the above- mentioned issues by means of an experimental program on RC frames with different Combinations of masonry infills. In addition, FE analysis is performed by modeling the masonry infills as (a) plate elements and (b) equivalent diagonal strut.

This research program is conducted at Adhiyamaan College of Engineering Hosur, Tamilnadu and Earthquake Engineering and Vibration Research Centre (EVRC), Central Power Research Institute (CPRI), Bengaluru. Two numbers of 3D RC frames having two bay and three storey and six numbers of 2D RC frames of one and two bays having one, two and three storeys are cast and tested with a number of configurations of masonry infill. The RC frames are designed as per Bureau of Indian Standards codes, IS 456-2000, "Plain and Reinforced Concrete-code of practice", IS1893-2002, "Criteria for earthquake resistant 
design of structures" and detailed as per IS 13920-1993, "Ductile Detailing of Reinforced Concrete Structures Subjected to Seismic Forces". A tri-axial shake table of size $3 \mathrm{~m}$ x $3 \mathrm{~m}$ with six degrees of freedom is used to conduct tests on the RC frames to evaluate their stiffness characteristics.

Masonry infills have a very high initial in-plane lateral stiffness and low deformability. Therefore, under seismic loads, the whole lateral force transfer mechanism of the structure (Figure 1.1) changes from a predominant frame action to predominant truss action. The change of frame mechanism to truss mechanism leads to a two-fold action. One, which in general is beneficial, it leads to reduction in bending moments and increase in axial forces in the frame members; and two, which is more severe, changes the natural frequency of the system significantly due to large stiffness addition which is generally not traded off completely by increase in mass due to walls. Paulay \& Priestley (1992) caution that although masonry infill may increase the overall lateral load capacity, it can result in altering structural response and attracting forces to different or undesired part of structure with asymmetric arrangement. This means that masonry infill may cause structural deficiencies.

Therefore, while analyzing the structures with masonry infill under seismic loads, due consideration must be given to the effect of infills on the frame response, otherwise, the results may be very erroneous. However, most of the designs are performed either by performing analysis of bare framed structures, without giving any due consideration to infills, or by following the empirical formulation suggested by various national and international standards for evaluation of natural frequency for framed structures with masonry infill. However, both the above-mentioned methods are not the best one for performing the analysis and design.

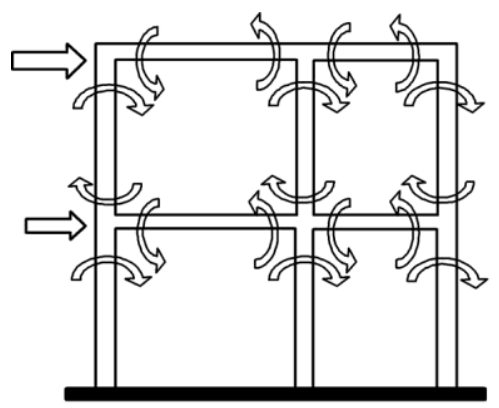

(a) Predominant frame action

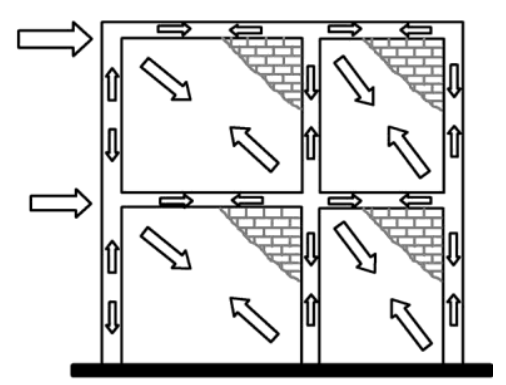

(b) Predominant truss action

Figure 1.1: Lateral load transfer mechanism due to masonry infill

The first method that is not giving any consideration to the masonry infill stiffness is definitely not correct as it always predicts the frequency at the lower side of actual frequency. The second method, that is

considering the empirical relations recommended by standards, gives good results in some particular cases, but more often than not, they also give results away from reality. This is because, the codal formulations generally do not give due considerations to the percentage and locations of masonry infills in framed structure.

The RC structures can have various kinds of configurations of masonry infills (Figure 1.2). The amount and location of infills greatly affect the natural frequency of the structural system. As discussed in literature review, many researchers have performed various tests and proposed various methodologies for performing analysis. However, still most of the engineers are not encouraged to use the analytical procedures proposed. It is well-understood that considering the masonry infills just as dead mass is grossly incorrect since it always over predicts the time period of structure due to no consideration of its stiffness. This generally under predicts the forces attracted by the structure, thus making the structures unsafe. Although, to avoid such ambiguities, and to make lives of designers simpler, various standards recommend certain expressions to empirically evaluate the time period of the structures. However, these expressions do not give due considerations to the amount and location for the infills. Most of the codes provide expressions which incorporate only height and width of the structure as variables. Few other codes recommend more detailed formulations giving due considerations to the walls in first storey only. The argument in support of giving consideration to only first storey walls is that the amount of infill panels in the first storey greatly influences, while those in the upper stories simply adds to the total mass of frames, and its contribution to the overall stiffness is considerably smaller (Kaushik, et al.

2006). 


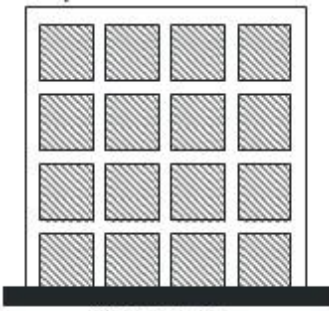

(a) Full Infills

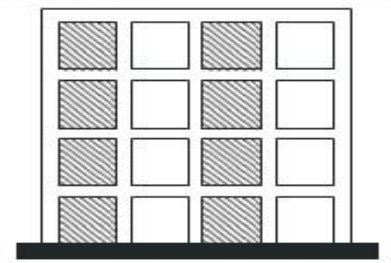

(d) Staggered Infills along bay

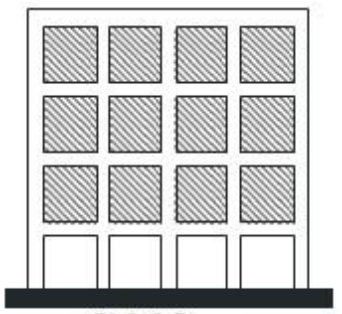

(b) Soft Storey

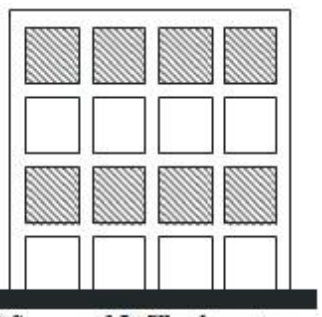

(c) Sta ggered Infills along storey

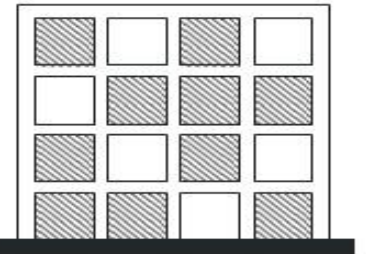

(e) Staggere d Infills along bay and storey

Figure 1.2: Various possible configurations of URM infill walls in a structure

It is true that the contribution of the first storey walls towards the overall stiffness is the greatest but, as shown later, it is incorrect to consider the walls beyond upper storeys just as dead mass. In this research work, the effect of location and amount of masonry infills in RC framed structure is investigated. It is found that the effect of stiffness gradually reduces and the effect of mass gradually increases as we go towards the upper stories.

\section{Objective And Scope Of The Work}

The main objectives of this research are

- To verify the adequacy of the codal formulations and numerical methods available in literature for evaluating the dynamic characteristics of RC frames with different patterns of masonry infills.

- Simple formulation for estimating the Natural Frequency of RC frames considering the location and amount of masonry infill in the structure.

- Response evaluation of 2D and 3D RC frames with masonry infills under dynamic loading.

A two phased experimental program is devised. In the first phase, shake table experiments are performed on six numbers of 2D RC frames varying from one-bay one-storey to two-bay three-storeys. Masonry infills are constructed and tests are performed with various locations of infill. This is done to study the effect of position and amount of infill in the structure and also for validation of the numerical model. In the second phase, two numbers of 3D RC framed structures with slabs and different arrangements of masonry infill are tested on shake table. These results are compared with results obtained from numerical model and also with the national and international codal formulations.

\section{Literature Review}

A large number of reinforced concrete and steel buildings are constructed with masonry infills. Masonry infills are often used to fill the void between the vertical and horizontal members of the building frames with the assumption that these infills will not take part in resisting any kind of load either axial or lateral; hence its significance in the analysis of frame is generally neglected. Moreover, non-availability of realistic and simple analytical models of infill and the complexity they introduce to analysis, generally keep them unaccounted. In fact an infill wall considerably enhances the strength and rigidity of the structure. It has been recognized that frames with infills have more strength and rigidity as compared to the bare frames and their ignorance has become the cause of failure of the many of the multi-storied buildings. Extensive researches are being carried out worldwide in the last five decades and many methods have been developed for the dynamic analysis of RC frames with infill panels incorporating one or more simplifying assumptions regarding its stiffness.

Extensive literature survey on the effect of masonry infills on reinforced concrete structures are presented in this chapter. This includes the analytical modeling, national and international codal provisions and experimental investigation carried out on various types of structures with and without infills. The first significant published research on infilled RC frames subjected to racking load was by Polyakov (1956). In order to determine the racking strength of infilled frames, Polyakov performed a number of large-scale tests on square and rectangular frames. Parameters investigated included the effects of the type of masonry units, mortar mixes, admixtures, methods of load application (monotonic or cyclic), and the effect of openings and test results provided ample testimony that a relatively weak Infill can contribute significantly to the stiffness and strength of an otherwise flexible frame.Smith (1966) investigated theoretically and 
experimentally the behaviour of diagonally loaded square infill frames and adapted the results to study the behavior of laterally loaded single and multi storey infilled frames. Frame and infill separated upon loading and stiffness response of the infill was influenced by the way in which the load was transferred from frame to infill. Diagonal cracking and compression failure were two observed modes of failure. The lengths of the contact between the frame and infill ' 'was represented approximately by,

$$
\frac{a}{l}=\frac{\pi}{2 \lambda} \quad--(3.1)
$$

where,

$$
\lambda l=\sqrt[l]{\frac{E_{m} t}{4 E_{f} \mathrm{I}_{f} l_{f}}} \quad \text {-- (3.2) }
$$

in which $l=$ a non-dimensional parameter expressing the relative stiffness of frame and infill, Em, $t$ and $l=$ the young's modulus, thickness and length of side of the infill respectively and $E f$, If and $l f=$ the young's modulus, second moment of area and length of side of the frame respectively.

Smith and Carter (1969) studied the behaviour of the multi-storey infill frames for lateral loading developing a design method based on an equivalent strut concept to predict the lateral stiffness of the composite frame. They experimentally showed that the diagonal stiffness and strength of the infilling panel depends not only on its dimensions and physical properties but also on its length of contact with the surrounding frame. The contact length, ' $\alpha h$ ', can be related with the relative stiffness of the infill to frame by the approximate equation

$$
\alpha_{h}=\frac{\pi}{2 \lambda_{h}} \quad---(3.3)
$$

where, $\lambda h$ is an empirical parameter expressing the relative stiffness of the frame to the infill and is given by,

$$
\lambda_{h}=\sqrt[4]{\frac{E_{m} t \sin 2 \theta}{4 E_{c} I_{c} h}} \quad \text {-- (3.4) }
$$

where;

$E m=$ Modulus of elasticity of masonry infill

$t=$ Thickness of masonry infill

$h=$ Height of masonry infill

$E c=$ Young's modulus of the column

$I c=$ Moment of inertia of the column

$\theta=$ Slope of the infill diagonal to the horizontal

This empirical parameter is related with only the column stiffness and it is propounded that whatever the beam stiffness is, beam contact length is always approximately half of its span.

Paulay and Priestley (1992) mentioned that at low levels of in-plane lateral force, the frame and infill panel act in a fully composite fashion, as a structural wall with boundary elements. As lateral deformations increase, the behavior becomes more complex as a result of the frame attempting to deform in flexural mode while the panel attempts to deform in a shear mode, as shown in Figure 3.1(a) and (b). The result is separation between frame and panel at the corners on the tension diagonal, and the development of a diagonal compression strut on the compression diagonal. Contact between frame and panel occurs for a length ' $z$ ', shown in Figure 3.1 (a). After separation, the effective width of the diagonal strut, ' $w$ ', shown in Figure 3.1(a), is less than that of the full panel. Natural-period calculations should be based on the structural stiffness after separation occurs. This may be found by considering the structure as an equivalent diagonally braced frame, where the diagonal compression strut is connected by pins to the frames corners. Figure 3.1(b) shows the equivalent system for a two-bay, four-story frame. Analytical expressions have been developed based on a beam-on-elastic-foundation analogy modified by experimental results which show that the effective width ' $w$ ' of the diagonal strut depends on the relative stiffness of frame and panel, the stress-strain curves of the materials, and the load level. However, since a high value of ' $w$ ' will result in a stiffer structure, and therefore potentially higher seismic response, it is reasonable to take a conservatively high value of ' $w$ ' assuming typical masonry infill properties and a lateral force level of $50 \%$ of the ultimate capacity of the infilled frame.

$w 0.25 d$

Where, $d$ is the diagonal length of masonry infill. 


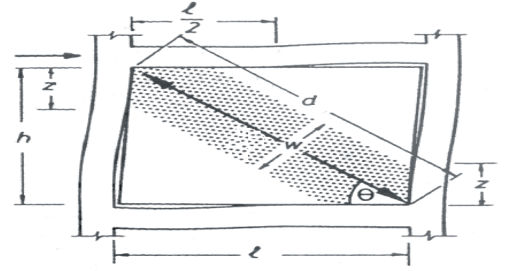

la) Deformation under shear load

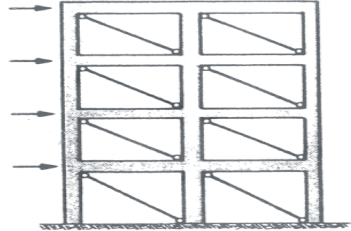

(b) Equivalent braced frame
for 2 bay. 2 story
infilled woll

Figure 3.1: Equivalent bracing action of masonry infill

According to FEMA 273 (1997), the elastic in-plane stiffness of a solid un- reinforced masonry infill panel prior to cracking shall be represented with an equivalent diagonal compression strut of width, w. The equivalent strut shall have the same thickness and modulus of elasticity as the infill panel it represents. These provisions were based on the early work of Mainstone and Weeks (1970) and Mainstone (1971). The thickness of strut ' $w$ ' is given by,

$$
w=0.175 d\left(\lambda_{h} h_{\text {eod }}\right)^{-0.4} \quad---(3.6)
$$

Where, $\lambda h=$ coefficient used to determine equivalent width of infill strut, given by

$$
\lambda_{h}=\sqrt[4]{\frac{E_{m} t \sin 2 \theta}{4 E_{c} I_{c} h}} \quad--(3.7)
$$

$h c o l=$ Column height between centerlines of beams, in .

$h=$ Height of infill panel, in.

$E c=$ Expected modulus of elasticity of column, psi

$E m=$ Expected modulus of elasticity of infill, psi

$I c=$ Moment of inertia of column, in. 4

$d=$ Diagonal length of infill panel, in.

$t=$ Thickness of infill panel and equivalent strut, in.

$\theta=$ Angle whose tangent is the infill height-to length aspect ratio, radians

Hendry (1998) suggested that although the analysis of infilled frame structures has been attempted using the theory of elasticity and by finite element analyses, the approximate solution would be appropriate due to the uncertain boundary conditions between the brickwork and the frame. Most of the approximations were based on the concept of equivalent diagonal strut, which was originally proposed by Polyakov (1960) and subsequently developed by other investigators. He modified the formulation proposed by Smith and carter (1969) for calculation of effective width of the equivalent diagonal strut by introducing a parameter for contact length of beam member of the infilled frame ' $\alpha L$ ' along with the parameter for contact length in the case of column of the infilled frame ' $\alpha h$ ' as shown in Figure 3.2.

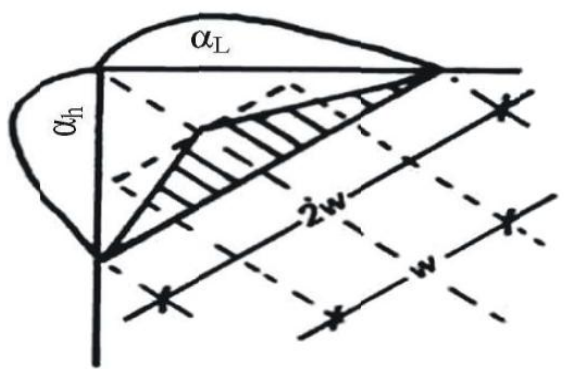

Figure 3.2: Effective width of equivalent diagonal strut

$\alpha_{h}=\frac{\pi}{2 \lambda_{h}}$

--- (3.8)

$\lambda h$ is an empirical parameter expressing the relative stiffness of the column to the infill given as; 


$$
\begin{aligned}
& \lambda_{h}=\sqrt[4]{\frac{E_{m} t \sin 2 \boldsymbol{\theta}}{4 E_{c} I_{c} h}} \\
& \alpha_{I}=\frac{\pi}{\lambda_{L}} \\
& \lambda_{L}
\end{aligned}
$$

$\lambda L$ is an empirical parameter expressing the relative stiffness of the beam to the infill given as;

$$
\lambda_{L}=\sqrt[4]{\frac{E_{m} t \sin 2 \theta}{4 E_{L} I_{L} l}} \quad \text {-- (3.11.) }
$$

Effective width of the equivalent diagonal strut ' $w$ ' is calculated by,

$$
w=\frac{1}{2} \sqrt{\alpha_{L}{ }^{2}+\alpha_{h}{ }^{2}} \quad \text {-- ( }\left(\begin{array}{ll}
3.12 \\
c
\end{array}\right)
$$

Where:

$E m=$ Modulus of elasticity of masonry infill

$t=$ Thickness of masonry infill

$h=$ Height of masonry infill

$l=$ Length of the beam

$E c=$ Modulus of elasticity of column

$E L=$ Modulus of elasticity of beam

Ic $=$ Moment of inertia of the column

$I L=$ Moment of inertia of the beam

$\theta=$ Slope of the infill diagonal to the horizontal (tan-1(h/l))

Kasım Armagan Korkmaz, et al. (2007) studied a 3-story RC frame structure with different amount of masonry infill walls to investigate the affect of infill walls on earthquake response of these type of structures. The diagonal strut approach was adopted for modeling masonry infill walls. Pushover curves were obtained for the structures using nonlinear analysis option of commercial software SAP2000 and the effects of irregular configuration of masonry infill wall on the performance of the structure were studied. The width of equivalent diagonal compression strut used in the analysis was based on FEMA 273 (1997) formula. The results of the study show that structural infill walls have very important effects on structural behavior under earthquake effects. Structural capacity under earthquake effect, displacement and relative story displacement were affected by the structural irregularities. The behavior of the structure with infilled walls can be predicted by means of simplified diagonal models.

\subsection{INTRODUCTION}

\section{Design And Construction Of Re Frames}

The response of the structure under dynamic loading depends on the characteristics of the structure such as natural frequencies, damping and mode shapes. The objective of this study is to develop a simple and effective method for the determination of natural frequencies of $\mathrm{RC}$ frames with infill. It is proposed to construct 2D RC frames and experimentally determine the natural frequencies using the shake table tests. This result will be used to validate the mathematical model developed. The dimensions of the 2D RC frames are finalised considering the available experimental facility.

\subsection{DESCRIPTION OF TEST SPECIMENS}

Six numbers of 2D RC frames of one and two bays having one, two and three storeys are cast. The RC frames are designed as per Bureau of Indian Standards codes, IS 456-2000, "Plain and Reinforced Concrete-code of practice", IS 1893-2002 (Part 1), "Criteria for earthquake resistant design of structures" and detailed as per IS 13920-1993, "Ductile detailing of Reinforced Concrete structures subjected to seismic forces". The concrete grade is M25 and both mild steel (MS) and Tor steel are used for reinforcement. Commercially available bricks are used for construction of masonry infill.

\subsection{DESIGN}

The RC frames comprises of footings, columns, beams and slabs. Analysis of the frames is done using STAAD Pro software. Dead load, imposed load, wind load and earthquake load are considered for analysis.Load Cases considered in the design of RC frames are, i) Dead load (DL) The dead load is considered as per IS 875-1987 (Part I-Dead loads), "Code of Practice for Design Loads (Other than Earthquake) for Buildings and Structures".

Unit weight of Reinforced Concrete

Unit weight of Brick

$$
\begin{aligned}
& =25 \mathrm{kN} / \mathrm{m} 3 \\
& =19.2 \mathrm{kN} / \mathrm{m} 3
\end{aligned}
$$


ii) Imposed Load (LL)

The imposed load is considered as per IS 875-1987 (Part II-Imposed loads), "Code of Practice for Design Loads (Other than Earthquake) for Buildings and Structures". Imposed load on slab $=2 \mathrm{kN} / \mathrm{m} 2$

iii) Wind Load (WL)

The wind load is considered as per IS 875-1987 (Part III-wind loads), "Code of Practice for Design Loads (Other than Earthquake) for Buildings and Structures".

Probability factor $k l$

Terrain, height and structure size factor $k 2$

$=1.00$

Topography factor $k 3$

$=1.05$

$=1.00($ slope less than 30$)$

Basic wind speed $V b$

Design wind speed $V z=V b \times \mathrm{k} 1 \times \mathrm{k} 2 \times \mathrm{k} 3$

$=55 \mathrm{~m} / \mathrm{s}$

Design wind pressure $P z=0.6 \times z^{2}$

$=57.75 \mathrm{~m} / \mathrm{s}$

$=2 \mathrm{kN} / \mathrm{m} 2$

iv) Earthquake Load (EL)

The earthquake load is considered as per the IS 1893-2002(Part 1). The factors considered are

Zone factor

Importance factor

$=0.36($ zone 5$)$

factor $=5.0$

Soil condition

Damping

$=$ Soft soil

$=5 \%$

v) Load Combinations

The following load combinations as per IS 875-1987 (Part 5-Special loads and combinations) "Code of Practice for Design Loads (Other than Earthquake) for Buildings and Structures".
a. $\quad 1.5(\mathrm{DL}+\mathrm{IL})$
b. $\quad 1.2(\mathrm{DL}+\mathrm{IL} \pm \mathrm{WL}$ or $\mathrm{EL})$
c. $\quad 1.5(\mathrm{DL} \pm \mathrm{WL}$ or $\mathrm{EL})$
d. $\quad 0.9 \mathrm{DL} \pm 1.5 \mathrm{WL}$ or $\mathrm{EL}$

\subsection{STEPS INVOLVED IN CONSTRUCTION OF RC FRAMES}

A rigid base frame of $3 \mathrm{~m} \times 3 \mathrm{~m}$ is fabricated using ISMC 250 channels and MS sheet of $12 \mathrm{~mm}$ thick. The RC frames are constructed on this base frame. Holes of $20 \mathrm{~mm}$ diameter are drilled over the surface of plate and inserts are provided similar to the spacing in the shake table.

\subsubsection{Formwork}

To construct concrete frames of required dimensions, the waterproof plywood sheet of $12 \mathrm{~mm}$ thick is used for preparing formwork. The inner surface of the wooden frame is greased / oiled to prevent the concrete mix from sticking on to the frame during removal of the wooden frame after casting.

\subsubsection{Footings}

Isolated footing with $600 \mathrm{~mm} \times 600 \mathrm{~mm}$ cross-section with a depth of $200 \mathrm{~mm}$ is provided for each column as shown in the Figures 4.1 (a) \& (b). Four holes of $25 \mathrm{~mm}$ diameter are provided in each footing so that the RC frames can be directly mounted on the shake table. Reinforcement of $6 \mathrm{~mm} \mathrm{MS}$ bars at $75 \mathrm{~mm} \mathrm{c/c}$ spacing are provided in both the directions in two layers one at the top and other at the bottom as the footings are expected to withstand both down thrust and uplift during testing.
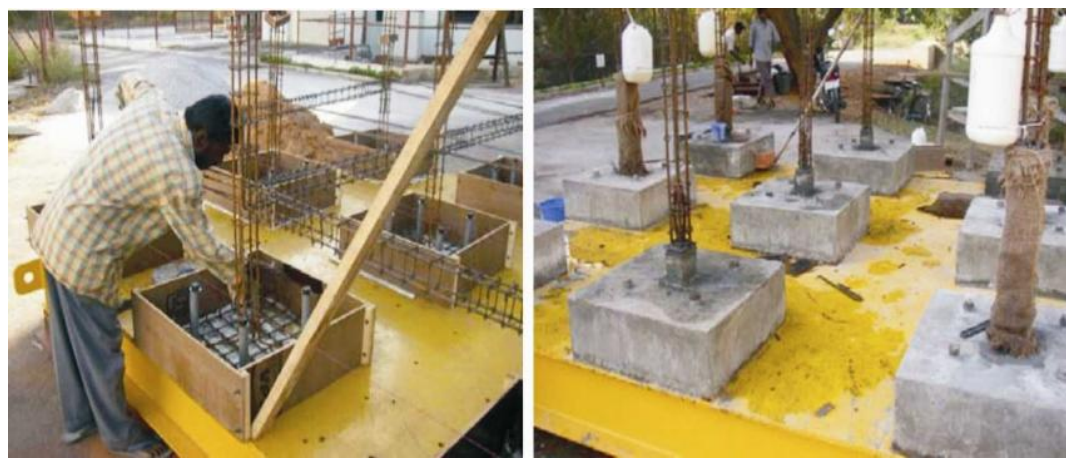

Figure4.1 (a) \& (b): Casting of Footings 


\subsubsection{Concreting}

The concrete mix for M25 grade is prepared using ordinary portland cement, fine sand and crushed gravel $(<10 \mathrm{~mm})$ as per mix design from IS 10262-1982 "Recommended Guidelines for Concrete Mix Design" shown in Table 4.1 with the ratio of 1:1.35:2.02 and water-cement ratio of 0.45. Cement, sand and stone aggregate are measured individually using weighing balance and mixed thoroughly to obtain consistent mix. Conveying of concrete mix is done with due care to avoid segregation. As per IS: 516- 1959, "Methods of tests for strength of concrete", three representative samples of $100100100 \mathrm{~mm}$ size cubes are cast and tested at each stage for checking the strength of the concrete as shown in Figure 4.2 (a) \& (b).

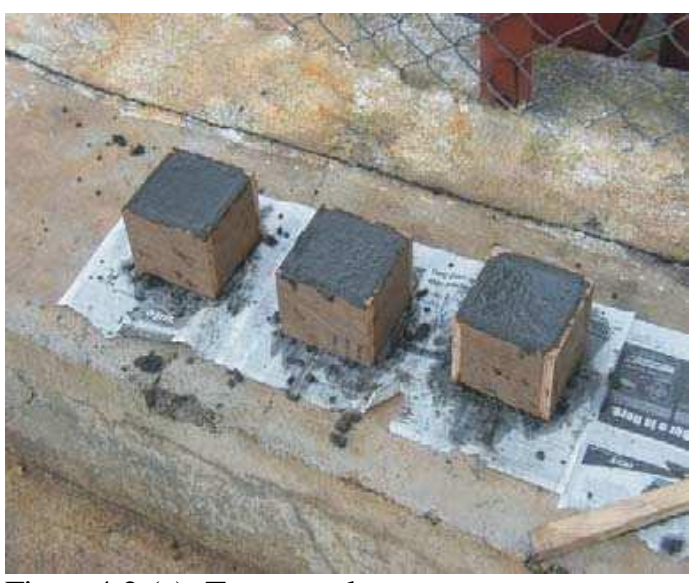

Figure4.2 (a): Test samples

Details of mix design

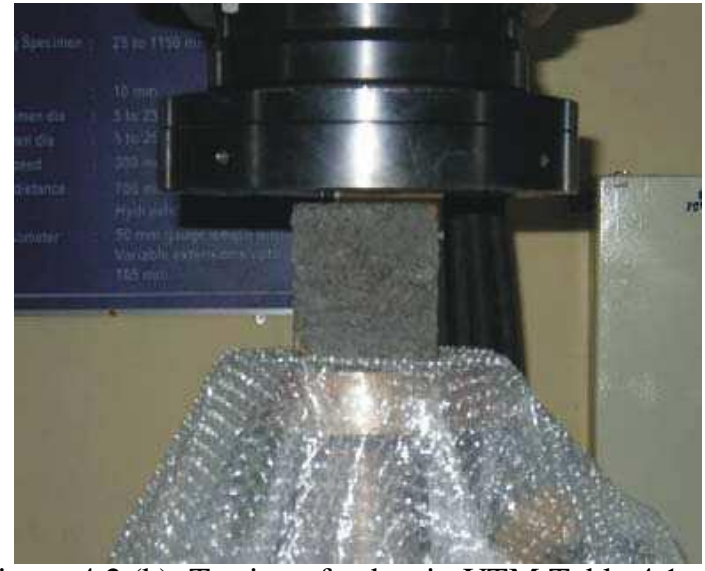

Figure 4.2 (b): Testing of cubes in UTM Table 4.1:

\begin{tabular}{|c|l|l|l|}
\hline SI no. & Reference & Design stipulations & Results \\
\hline 1 & IS : 10262-1982 & Characteristiccompressivestren gthfor 28 days & $25 \mathrm{~N} / \mathrm{mm}^{2}$ \\
\hline 2 & & Maximum size of aggregate & $10 \mathrm{~mm}$ \\
\hline 3 & $\begin{array}{l}\text { Appendix }- \text { A of } \\
\text { IS: 10262-1982 }\end{array}$ & Degree of quality control & Good \\
\hline 4 & $\begin{array}{l}\text { Table 3 of } \\
\text { IS: 456-2000 }\end{array}$ & Type of exposure & Mild \\
\hline 5 & & Ce & ment used \\
\hline 6 & Target mean stren gth & $=$ fck + 1.65 $\times$ s & $33.745 \mathrm{~N} / \mathrm{mm}^{2}$ \\
\hline 7 & $\begin{array}{l}\text { Figure 1 of } \\
\text { IS: 10262-1982 }\end{array}$ & Water cement ratio & 0.45 \\
\hline 8 & Mix Proportions & Cement & 1.00 \\
& & Fine aggregate Coarse aggregate & 1.35 \\
& & Water/Cement ratio & 2.02 \\
& & & 0.45 \\
\hline
\end{tabular}

\subsubsection{Beams} below.

All the beams of 2D RC frames are of size $75 \mathrm{~mm} \times 100 \mathrm{~mm}$. The reinforcement details are given

a) Longitudinal Reinforcement

The top as well as bottom reinforcement consists of 2 nos. of $6 \mathrm{~mm}$ MS bars and 2 nos. of $8 \mathrm{~mm}$ Tor throughout the member length for the first and second 3D frame respectively. At the beam-column junction, both the top and bottom bars of the beam are provided with adequate development length as per IS 13920-1993 (Development length +10 times diameter of bar as per codal provisions).

b) Shear Reinforcement:

Shear reinforcement consists of vertical rectangular hoops. The diameter of the stirrup used is $3 \mathrm{~mm}$ MS bars. The spacing of stirrups is $75 \mathrm{~mm} \mathrm{c} / \mathrm{c}$. At the beam-column junction, stirrups are spaced at a distance of $50 \mathrm{~mm} \mathrm{c/c}$ from the joint face up to a length of $200 \mathrm{~mm}$ on either side of the junction where flexural yielding may occur under the effect of lateral forces. 
4.4.5 Columns

The overall dimensions of the columns of 2D RC frames are of size $75 \mathrm{mmx} 100 \mathrm{~mm}$. The reinforcement details are given below Hinge support.

\subsubsection{Slabs}

The thickness of slab is $50 \mathrm{~mm}$. The reinforcement of $6 \mathrm{~mm}$ MS bars at $100 \mathrm{~mm} \mathrm{c} / \mathrm{c}$ in both directions in two layers, one at the top and other at the bottom of the slab are Provided as shown in Figure 4.3 as reversal of stresses are expected to occur during shake table testing.

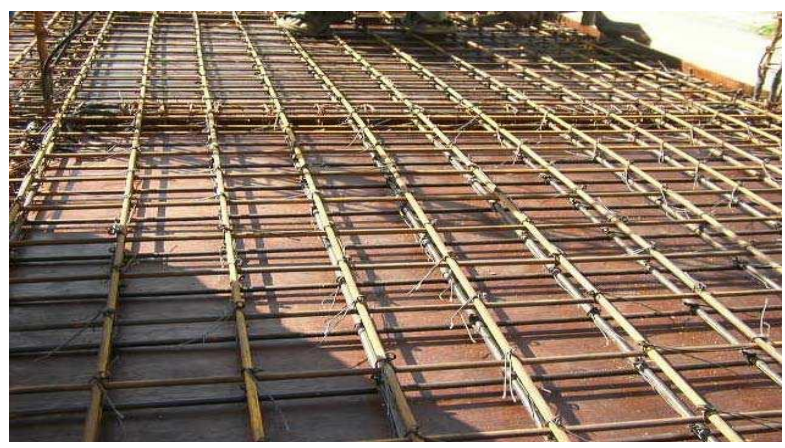

Figure 4.3: Slab reinforcement

\section{Equivalent Diagonal Strut}

The presence of infill affects the distribution of lateral loads in the framed structure because of the increase of stiffness. The study of interaction of infill with frames has been attempted by using rigorous analysis like finite element analysis or theory of elasticity. But due to uncertainty and complexity in defining the interface conditions between infill and the frames, many approximate methods are being developed. One of the most common and popular approximations is, replacing the masonry infill by equivalent diagonal strut whose thickness is equal to the thickness of the masonry infill. The main problem in this approach is to find the effective width of the equivalent diagonal strut. Many researchers have suggested different method to find the width of equivalent diagonal strut. The width of strut depends on the length of contact between the wall and the columns, ' $\boldsymbol{\alpha h}$ ', and between the wall and beams, ' $\alpha \boldsymbol{L}$ ' as shown in Figure 5.1. The width of the equivalent diagonal strut varies between, one-third to one-tenth of the diagonal length of masonry infill.

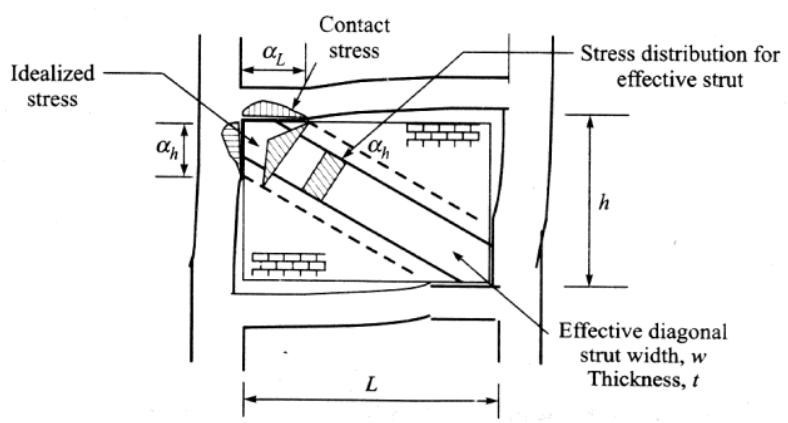

Figure 5.1: Equivalent diagonal strut (Drydale, et al. 1994)

\subsection{CALCULATION OF WIDTH OF EQUIVALENT DIAGONAL STRUT}

1) Smith and Carter (1969) are the first to propose the formula to find the width of the equivalent diagonal strut on the basis of beam on an elastic foundation. Most of the methods proposed later are generally based on this work.

The column contact length, ' $\alpha h$ ', is related with the relative stiffness of the infill to frame by the approximate equation

$$
\alpha_{n}=\frac{\pi}{2 \lambda_{n}}
$$

and beam contact length ' $\alpha \mathrm{L}$ ' is taken approximately half of its span. The width ' $w$ 'of the strut is given by

$w=\sqrt{\alpha_{L}{ }^{2}+\alpha_{h}{ }^{2}}$ 
' $\lambda h$ ' is an empirical parameter expressing the relative stiffness of the column to the infill

$\lambda_{h}=\sqrt[4]{\frac{E_{m} t \sin 2 \theta}{4 E_{e} e_{e} h}}$

where;

$E m=$ Modulus of elasticity of masonry infill

$t=$ Thickness of masonry infill

$h=$ Height of masonry infill

$E c=$ Modulus of elasticity of column

$I c=$ Moment of inertia of the column

$\theta=$ Slope of the infill diagonal to the horizontal

2 )Paulay and Priestley (1992) proposed a formula for finding the width of the

Equivalent diagonal strut ' $w$ '

$w 0.25 d$

masonry infill.

--- (5.4) Where, ' $d$ ' is the diagonal length of the

3) FEMA 273 (1997), "NEHRP Guidelines for the Seismic Rehabilitation of Buildings" mentioned that the equivalent diagonal strut shall have the same thickness and modulus of elasticity as the infill panel it represents and width be calculated using the formula based on the early work of Mainstone and Weeks (1970) and Mainstone (1971).

$W=0.175 d\left(\mathrm{~h}_{\mathrm{co}}\right)^{-1.4}$

where, $\lambda h=$ coefficient used to determine equivalent width of infill strut, given by

$\lambda_{h}=\sqrt[4]{\frac{E_{m} t \sin 2 \theta}{4 E_{e} I_{e} h}}$

$h c o l=$ Column height between centerlines of beams, in.

$h=$ Height of infill panel, in.

$E c=$ Expected modulus of elasticity of column, psi

$E m=$ Expected modulus of elasticity of infill, psi

$I c=$ Moment of inertia of column, in. 4

$d=$ Diagonal length of infill panel, in.

$t=$ Thickness of infill panel and equivalent strut, in.

$\theta$ Angle whose tangent is the infill height-to length aspect ratio, radians

4) Hendry (1998) introduced a parameter for contact length of beam member of the infilled frame ' $\alpha L$ ' in addition to the parameter for contact length in the case of column of the infilled frame ' $\alpha h$ ' given by,

$$
\alpha_{h}=\frac{\pi}{2 \lambda_{n}}
$$

Where, $\lambda h$ is an empirical parameter expressing the relative stiffness of the column to the infill an is given by;

$\lambda_{h}=\sqrt[4]{\frac{E_{m} t \sin 2 \theta}{4 E_{e} I_{e} h}}$

And,

$\alpha_{2}=\frac{\pi}{\lambda_{2}}$

Where, $\lambda L$ is an empirical parameter expressing the relative stiffness of the beam to the infill given as;

$\lambda_{2}=\sqrt[4]{\frac{E_{m} t \sin 2 \theta}{4 E_{2} I_{L} l}}$

Effective width of the equivalent diagonal strut ' $w$ ' is calculated by,

$w=\frac{1}{3} \sqrt{\alpha_{z^{2}}+\alpha_{i}{ }^{2}}$

where; 
$l=$ Length of the infill

$I L=$ Moment of inertia of beam

$E L=$ Modulus of elasticity of beam

5)In this present study (Ravi, 2011) a new method is proposed for calculating width of the equivalent diagonal strut based on the work of Smith and Carter.

$\alpha_{n}=\frac{\pi}{2 \lambda_{n}}$

where, ' $\lambda \mathrm{h}$ ' is an empirical parameter expressing the relative stiffness of the column to the infill and is given by,

$\lambda_{n}=\sqrt[4]{\frac{E_{m} t \sin 2 \theta}{4 E_{e} I_{e} h}}$

Assuming $\boldsymbol{\alpha} \boldsymbol{L}=\boldsymbol{\alpha} \boldsymbol{h}$, where $\alpha \boldsymbol{L}$ is a parameter for contact length of beam member with the infill, the width ' $w$ ' of the equivalent diagonal strut is given by

$w=\sqrt{\alpha_{2}{ }^{3}+\alpha_{1}{ }^{3}}$

$w=1.414 a_{h}$

A typical calculation is carried out to find the width of the equivalent diagonal strut which is same for both 2D RC frames with masonry infill in this study, using all the above methods and the results are tabulated in Table 5.1.

\subsubsection{Parameters to find equivalent diagonal strut}

Breadth of Beam / Column, $b$

Depth of Beam / Column, $d$

$=0.075 \mathrm{~m}$

Thickness of masonry infill, $t$

$=0.1 \mathrm{~m}$

$=0.075$

Height of masonry infill, $h$

$=0.8 \mathrm{~m}$

Length of masonry infill, $l$

$=1.1 \mathrm{~m}$

Diagonal length of masonry infill, $d$

$=1.36 \mathrm{~m}$

Height of column, hcol

$=0.9 \mathrm{~m}$

Moment of Inertia of Beam / Column

$=6.25 \times 10-6 \mathrm{~m} 2$

Modulus of elasticity of concrete

$=2.5 \times 107 \mathrm{kN} / \mathrm{m} 2$

Modulus of elasticity of masonry infill

Slope of the infill diagonal to the horizontal, $\theta$

$=1.4 \times 107 \mathrm{kN} / \mathrm{m} 2$

$=0.6288$ radians

Table 5.1: Width of Equivalent diagonal strut

\begin{tabular}{|c|l|c|}
\hline SI no. & \multicolumn{1}{|c|}{ Methods } & Width (m) \\
\hline 1. & Smith and Carter & 0.598 \\
\hline 2. & Paulay and Priestley & 0.340 \\
\hline 3. & FEMA 273 & 0.116 \\
\hline 4. & Hendry & 0.280 \\
\hline 5. & Ravi & 0.332 \\
\hline
\end{tabular}

These widths of equivalent diagonal strut are used for FE analysis of 2D RC frames with various configurations of masonry infill.

\section{Comparison Of Width Of Equivalent Diagonal Strut By Various Methods}

The widths of the equivalent diagonal strut are calculated using all the five methods for different aspect ratios starting from $0.25: 1.00$ to 2.00:1.00, height to length of masonry infill keeping all the other parameters same, as shown in Table 6.1. 


\begin{tabular}{|c|c|c|c|c|c|c|c|c|c|}
\hline Aspect Ratio & Smith a & od Carter & Paulay and Priestley & FEI & 273 & & adry & & aví \\
\hline$(k i)$ & with $\theta$ & without $\theta$ & No $\theta \mathrm{term}$ in this method & with $\theta$ & without $\theta$ & with $\theta$ & witbout $\theta$ & with $\theta$ & without $\theta$ \\
\hline $0.25: 1.00$ & 0.542 & 0.529 & 0.258 & 0.123 & 0.114 & 0314 & 0.260 & 0.296 & 0.245 \\
\hline $0.50-1.00$ & 0546 & 0.541 & 0.280 & 0.109 & 0.107 & 0.281 & 0266 & 0.308 & 0.292 \\
\hline $0.75: 1.00$ & 0.551 & 0.550 & 0.313 & 0.108 & 0.108 & 0.273 & 0.271 & 0.326 & 0.323 \\
\hline $1.00: 1.00$ & 0.557 & 0.557 & 0.354 & 0.113 & 0.113 & 0.274 & 0.274 & 0.347 & 0.347 \\
\hline $1.25: 1.00$ & 0.564 & 0.563 & 0.400 & 0.121 & 0.121 & 0.279 & 0.278 & 0.369 & 0.367 \\
\hline $1.50: 1.00$ & 0.572 & 0.569 & 0.451 & 0.131 & 0.130 & 0.286 & 0200 & 0.392 & 0.384 \\
\hline $1.75: 1.00$ & 0579 & 0.574 & 0.504 & 0.141 & 0.139 & 0.294 & 0.283 & 0.414 & 0.399 \\
\hline $200: 1.00$ & 0.568 & 0.579 & 0.559 & 0.152 & 0.148 & 0.302 & 0.285 & 0.436 & 0.413 \\
\hline
\end{tabular}

Note: " $\theta$ is angle of masony infill diagonal with respet to the horixuetal axis

Table 6.1 comparision Table

\subsection{COMPARISON OF RESULTS}

1. The width of equivalent diagonal strut obtained using the formulations of all the five methods considered in this research work are tabulated in Table 6.2.The aspect ratio of height to length is same for all the 2D RC frames and hence only one width of equivalent diagonal strut for each method is calculated for all the configurations in this research work.

Table 6.2: Width of Equivalent diagonal strut

\begin{tabular}{|c|l|c|}
\hline SI No. & \multicolumn{1}{|c|}{$\begin{array}{c}\text { M } \\
\text { e }\end{array}$} & Width (m) \\
\hline 1. & Smith \& Carter & 0.598 \\
\hline 2. & Paulay \& Priestley & 0.340 \\
\hline 3. & FEMA 273 & 0.116 \\
\hline 4. & Hendry & 0.280 \\
\hline 5. & Ravi & 0.332 \\
\hline
\end{tabular}

2. The width of the equivalent diagonal strut calculated using all the five methods for differentaspectratios varying from $0.25: 1.00$ to 2.00:1.00, height to length of masonry infill keeping all the other parameters same are shown in Table 6.2. From the Tables 6.1 and 6.2 it can be observed that the width of equivalent diagonal strut by Stafford Smith and Carter method always gives a high value, FEMA 273 gives the least value and the other three methods are in between these two methods. From the Table 6.2, it can be observed that the values of the width of equivalent diagonal strut are almost same between the aspect ratios 0.50:1.00 to $1.75: 1.00$ (i.e. from 30 o to $60 \mathrm{o}$ with respect to horizontal) with and without $\theta$, hence ' $\operatorname{Sin} 2 \theta$ ' term can be neglected in all the methods when the aspect ratio varies between 0.50:1.00 to 1.75:1.00. Paulay and Priestley method is an exemption for this as no $\theta$ term exists in its formulation.

Table 6.3 width of the equivalent diagonal strut for different aspect ratio (mm)

\begin{tabular}{|c|c|c|c|c|c|c|c|c|c|}
\hline Aspect Ratio & Smith a & ad Carter & Paulay and Priestley & & 1273 & & adry & & avi \\
\hline$(k i)$ & with $\theta$ & without $\theta$ & $\mathrm{No}_{0} \theta \mathrm{tem}$ in this method & with $\theta$ & without $\theta$ & with $\theta$ & witbout $\theta$ & with $\theta$ & witbout $\theta$ \\
\hline $0.25: 1.00$ & 0.542 & 0.529 & 0.258 & 0.123 & 0.114 & 0.314 & 0.260 & 0.296 & 0.245 \\
\hline $0.50: 1.00$ & 0546 & 0.541 & 0280 & 0.109 & 0.107 & 0.281 & 0.266 & 0.308 & 0.292 \\
\hline $0.75: 1.00$ & 0551 & 0.550 & 0313 & 0.108 & 0.108 & 0.273 & 0.271 & 0.326 & 0.323 \\
\hline $1.00: 1.00$ & 0557 & 0.557 & 0334 & 0.113 & Q.113 & 0274 & 0.274 & 0347 & 0347 \\
\hline $1.25: 1.00$ & 0.564 & 0.563 & 0.400 & 0.121 & 0.121 & 0.279 & 0.278 & 0.369 & 0.367 \\
\hline $1.50: 1.00$ & 0572 & 0.569 & 0.451 & 0.131 & 0.130 & 0.286 & 0280 & 0.392 & 0.384 \\
\hline $1.75: 1.00$ & 0.579 & 0.574 & 0504 & 0.141 & 0.139 & 0.294 & $02 \times 3$ & 0.414 & 0.399 \\
\hline $200: 1.00$ & 0.568 & 0.579 & 0559 & 0.152 & 0.148 & 0.302 & 0285 & 0.436 & 0.413 \\
\hline
\end{tabular}

Noce: 'f is angle of masonny infill diagnall with respect to the borixetal axis 


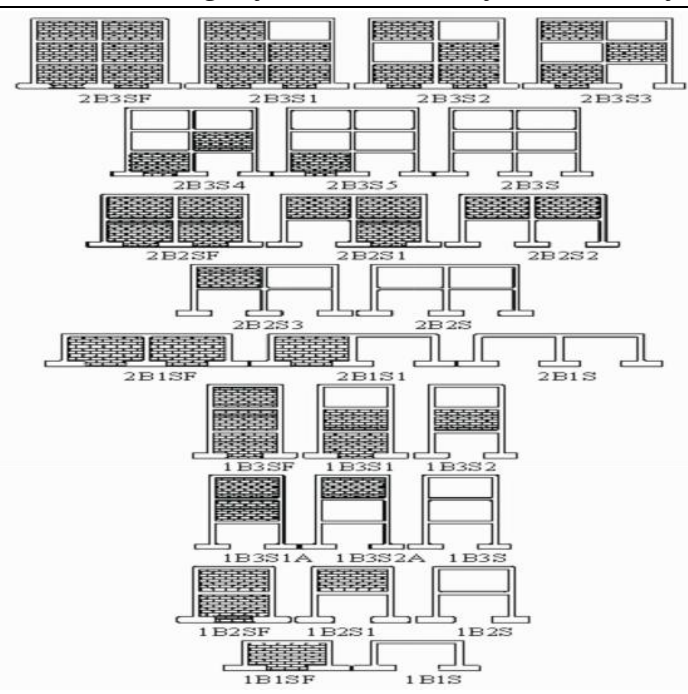

Figure 6.1: Various Configurations of masonry infill in 2D RC frames

3. Natural frequencies obtained from $\mathrm{FE}$ analyses carried out on 2D RC frames modeling the masonry infill as plate elements and equivalent diagonal strut using the proposed formulation are compared with the shake table test results for 2D RC frames as shown in Table 6.3 for various configurations of masonry infill as shown in Figure 6.1. The plate elements due to its rigidity with the frame increase the stiffness in the frames and hence give large values of natural frequencies which is not true.The results obtained from the proposed method matches well with the shake table results.

4. In Table 6.4 the natural frequencies obtained for 2D RC frames from the $\mathrm{FE}$ analysis using the formulations for calculating the width of equivalent diagonal strut by all the five methods are compared with the natural frequencies obtained by shake table tests.

Table 6.3: Comparison of natural frequencies of 2D RC frames modeling the masonry infill as plate element and proposed strut model with shake table results $(\mathrm{Hz})$

\begin{tabular}{|l|c|c|c|}
\hline Model & Plate Element & $\begin{array}{c}\text { Proposed strut Model } \\
\text { (Ravi. R) }\end{array}$ & Shake table test \\
\hline 2B3SF & 77.89 & 30.47 & 29.50 \\
\hline 2B3S1 & 85.34 & 41.78 & 36.00 \\
\hline 2B3S2 & 75.90 & 34.06 & 30.00 \\
\hline 2B3S3 & 62.65 & 29.40 & 26.25 \\
\hline 2B3S4 & 39.10 & 27.88 & 25.75 \\
\hline 2B335 & 20.68 & 19.84 & 19.25 \\
\hline 2B3S & $14.13 *$ Bare RC frame & 44.50 & 14.00 \\
\hline 2B2SF & 129.93 & 37.25 & 32.00 \\
\hline 2B2S1 & 96.13 & 16.58 & 15.00 \\
\hline 2B2S2 & 18.79 & 17.87 & 15.50 \\
\hline 2B2S3 & 21.92 & & 19.25 \\
\hline 2B2S & $21.25 *$ Bare RC frame & $* *$ \\
\hline 2B1SF & 254.02 & 115 & 39.75 \\
\hline 2B1S1 & 161.66 & 102 & 29 \\
\hline 2B1S & $11.42 *$ Bare RC frame & & 34 \\
\hline 1 B3SF & 60.44 & 30.54 & 20.75 \\
\hline 1 B3S1 & 43.39 & 36.42 & 12.75 \\
\hline 1B3S2 & 18.46 & 18.28 & 11.25 \\
\hline 1B3S1A & 15.08 & 12.57 & 14.00 \\
\hline 1B3S1A & 10.67 & 11.03 & 42.75 \\
\hline 1B3S & $14.31 *$ Bare RC frame & & \\
\hline 1B2SF & 111.64 & 44.62 & \\
\hline
\end{tabular}


Xperimental Studies On Characterising Of A seismic Performance Of Reinforced Concrete Frames

\begin{tabular}{|l|c|c|c|}
\hline $1 \mathrm{~B} 2 \mathrm{~S} 1$ & 20.89 & 17.70 & 16.5 \\
\hline $1 \mathrm{~B} 2 \mathrm{~S}$ & $22.42 *$ Bare RC frame & 20.00 \\
\hline $1 \mathrm{~B} 1 \mathrm{SF}$ & 246.42 & 114 & $* *$ \\
\hline $1 \mathrm{~B} 1 \mathrm{~S}$ & $43.14 *$ Bare RC frame & 41.25 \\
\hline
\end{tabular}

Table 6.4: Comparison of natural frequencies of 2D RC frames obtained from all five methods for equivalent

diagonal strut with the shake table test results $(\mathrm{Hz})$

\begin{tabular}{|c|c|c|c|c|c|c|}
\hline Model & Shake table & $\begin{array}{l}\text { Smith \& } \\
\text { carter }\end{array}$ & \begin{tabular}{|l} 
Paulay \& \\
Priestley
\end{tabular} & FEMA & Hendry & Ravi. $\mathbf{R}$ \\
\hline $2 \mathrm{~B} 3 \mathrm{SF}$ & 29.50 & 30.99 & 30.52 & 24.53 & 29.94 & 30.47 \\
\hline $2 \mathrm{~B} 3 \mathrm{~S} 1$ & 36.00 & 43.08 & 41.87 & 34.09 & 41 & 41.78 \\
\hline $2 \mathrm{~B} 3 \mathrm{~S} 2$ & 30.00 & 35.39 & 34.14 & 27.55 & 33.4 & 34.06 \\
\hline $2 \mathrm{~B} 3 \mathrm{~S} 3$ & 26.25 & 29.91 & 29.46 & 23.93 & 28.9 & 29.40 \\
\hline $2 \mathrm{~B} 3 \mathrm{~S} 4$ & 25.75 & 28.62 & 27.92 & 24.88 & 27.55 & 27.88 \\
\hline 2B3S5 & 19.25 & 20.07 & 19.85 & 19.05 & 19.74 & 19.84 \\
\hline $2 \mathrm{~B} 3 \mathrm{~S}$ & 14.00 & \multicolumn{5}{|c|}{$14.13 *$ Bare RC frame } \\
\hline $2 \mathrm{~B} 2 \mathrm{SF}$ & 42.00 & 47.71 & 44.68 & 32.35 & 43.08 & 44.50 \\
\hline 2B2S1 & 35.00 & 42.69 & 37.52 & 22.76 & 35.15 & 37.25 \\
\hline 2B2S2 & 15.00 & 15.47 & 16.55 & 17.03 & 16.75 & 16.58 \\
\hline 2B2S3 & 15.50 & 16.65 & 17.84 & 18.68 & 18.1 & 17.87 \\
\hline $2 \mathrm{~B} 2 \mathrm{~S}$ & 19.25 & \multicolumn{5}{|c|}{$21.25 *$ Bare RC frame } \\
\hline 2B1SF & $* *$ & 123.16 & 115.43 & 86.81 & 111.63 & 115 \\
\hline 2B1S1 & $* *$ & 112.85 & 102.49 & 75.47 & 98.28 & 102 \\
\hline 2B1S & 39.75 & \multicolumn{5}{|c|}{$41.42 *$ Bare RC frame } \\
\hline 1B3SF & 29 & 29.97 & 30.54 & 27.26 & 30.42 & 30.54 \\
\hline 1B3S1 & 34 & 37.32 & 36.47 & 33.18 & 36.04 & 36.42 \\
\hline 1B3S2 & 20.75 & 17.34 & 18.25 & 18.54 & 18.42 & 18.28 \\
\hline 1B3S1A & 12.75 & 11.58 & 12.54 & 13.04 & 12.74 & 12.57 \\
\hline 1B3S1A & 11.25 & 10.29 & 10.71 & 11.52 & 11.18 & 11.03 \\
\hline 1B3S & 14.00 & \multicolumn{5}{|c|}{$14.31 *$ Bare RC frame } \\
\hline 1B2SF & 42.75 & 45.41 & 44.7 & 35.78 & 43.87 & 44.62 \\
\hline 1B2S1 & 16.5 & 16.38 & 17.66 & 19.33 & 17.92 & 17.70 \\
\hline 1B2S & 20.00 & \multicolumn{5}{|c|}{$22.42 *$ Bare RC frame } \\
\hline 1B1SF & ** & 123.92 & 114.5 & 84.38 & 110.17 & 114 \\
\hline
\end{tabular}

Note: Frequency range of operation for shake table test is only between 0-50 Hz.

** indicates that the natural frequency is out of the test range $(>50 \mathrm{~Hz})$

VII. Conclusions

Experimental and numerical studies are carried out on 2D RC frames under various configurations of masonry infill in addition to bare frames. The $\mathrm{RC}$ frames are designed and detailed as per the relevant Indian standard codes. A simple numerical method has been formulated to obtain the natural frequencies of RC frames with masonry infill in the FE analysis. Tri-axial shake table is used for the determination of natural frequencies experimentally. These results are compared with the empirical formulae given in national and international codes for finding the natural frequencies. The following are the major conclusions:

1. The masonry infills, although do not interfere in the vertical load resisting system for the RC frame structures, they significantly affect the lateral load-resisting system of the same.

2. For all the aspect ratios of height to length of masonry infill, Smith and Carter method gives the high value and FEMA gives the least value for the width of the equivalent diagonal strut. Whereas the methods proposed by Paulay and Priestley, Hendry and Ravi give intermediate values for the width.

3. Paulay and Priestley is the simplest of all the methods as its formulation is only 0.25 times the diagonal length of the masonry infill and do not give due considerations to the characteristics of the masonry infill.

4. In all the methods where ' $\theta$ ' is involved, the ' $\operatorname{Sin} 2 \theta$ ' term can be neglected when the aspect ratios varies from $0.5: 1.00$ to $1.75: 1.00$ height to length of masonry infill (angle of diagonal strut varying from $30 \mathrm{o}$ to 
60 o with respect to horizontal).

5. The natural frequency of the structure with complete infill is significantly higher than the natural frequency of the bare framed structure. In most of the cases, the natural frequencies of the frames with complete infills are found to be around twice as that of the bare framed structures.

6. The FE analysis considering infill as plate elements with complete rigidity with the RC frames do not predict the natural frequency correctly due to the high stiffness offered by the elements. Hence, the numerical analysis can be done considering infill as strut member.

7. By comparing the results of $2 \mathrm{~B} 3 \mathrm{SF} \& 1 \mathrm{~B} 3 \mathrm{SF}, 2 \mathrm{~B} 2 \mathrm{~S} 2 \& 1 \mathrm{~B} 2 \mathrm{~S} 1,2 \mathrm{~B} 3 \mathrm{~S} \& 1 \mathrm{~B} 3 \mathrm{~S}$ it can be said that the natural frequency does not depend on the number of bays, whether it is bare, complete infill or infill with similar type of openings in the subsequent bays. Hence, the natural frequency of the structure is independent of the number of bays.

8. The reduction in the natural frequency is more, when the infill is removed in the lower floor as compared to the removal of infill in the upper floors as can be seen from the 2B3S5 \& 2B3S and 2B3S3 $\&$ 2B3S4 tests. This is due to the contribution of infill towards the stiffness being more in the lower floors as compared to the upper floors.

9. Similarly, there is an increase in the natural frequency when the infill is removed from the upper floors as observed from 1B3S2A \& 1B3S and $1 \mathrm{~B} 2 \mathrm{~S} 1 \& 1 \mathrm{~B} 2 \mathrm{~S}$. From this we can conclude that the contribution of infill towards the mass being more in the upper floors as compared to the lower floors.

10. The natural frequencies and damping values both in $2 \mathrm{D} \mathrm{RC}$ frames will be high in the presence of masonry infill. Hence the role of masonry infill in resisting the lateral forces like earthquake and wind is significant and has to be accounted during designing of the structures.

11. Indian code and Euro code which are similar to many international codes predicts with reasonable accuracy the natural frequencies of the bare RC frames. But these standards give less value of natural frequencies when the masonry infill exists. Indian code does not consider the position or amount of infill present in the structure, whereas Euro code gives importance to the masonry in the first storey but the results of the Indian code are better compared to Euro code.

12. The prediction of natural frequencies for 2D RC frames with masonry infill using the proposed formulation for the width of equivalent diagonal strut in FE analysis matches reasonably well with the shake table test results and is better compared to the results obtained using codal provisions.

\section{References}

[1] Alidad Hashemi \& Khalid Mosalam (2006), "Shake table experiment on reinforced concrete structure containing masonry infill wall”, Earthquake engineering and structure dynamic, Vol 35; 1827-1852

[2] Diptesh Das and C.V. Murty (2004), "Brick masonry infills in seismic design of RC frame buildings: Part 2-Behaviour, The Indian Concrete Journals, 31-38

[3] Drydale R.G, Hamid A.A and Baker L.R, (1994), "Masonry structures-Behaviour and Design", Prentice Hall, Englewood cliffs, New Jersey, USA

FEMA 273, (1997), NEHRP guidelines for the seismic rehabilition of builbings, Applied Technology Council, USA

[5] Han-Seon Lee and Sung-Woo Woo (2002), "Effect of Masonry infills on seismic Performance of a 3-Storey RC Frame with Non Seismic Detailing", Earthquake engineering and structural dynamics, Vol 31, 353-378

[6] Hendry.A.W, (1998), Structural Masonry, $2^{\text {nd }}$ edition, Macmillan Press, UK

[7] Kasim Armagan Korkmaz, Fuat Demir and Mustafa Sivri (2007), "Eartquake Assessment of R/C Structures with Masonry Infill Walls", International Journal of Science \& Technology, volume 2, 155-164.

[8] Kaushik, H.B., Durgesh C. Rai and Sudhir K. Jain (2006), "Code Approaches to Seismic Design of Masonry-Infilled Reinforced Concrete Frames: A State-of-the-Art Review”, Earthquake Spectra, Vol 22, No. 4, November 2006, $961-983$.

[9] Klinger R.E, Rubiano N.R and Bhashandy S.C (1997), "Evaluation and analytical Verification of shaking table data from infilled frames", The Masonry Society Journal, The Masonry Society, USA; 15(2), 33-41

[10] Paulay T and Priestley, M.J.N (1992), "Seismic Design of Concrete and Masonry Buildings", John Wiley \& Sons Inc., New York, USAPerumal Pillai.E.B and Govindan.P (1994), "Structural response of brick infill in R.C. frames", International Journal of Structures, Vol. 14, No.2, 83-102

[11] Crewe and Colin A. Taylor (2001), "Shaking table tests of 1:4 reduced-scale models of masonry infilled reinforced concrete frame buildings", Earthquake Engineering and Structural Dynamics, Vol-30, 819-834

[12] Smith B.S and Carter C (1969), "A method of analysis for infilled frames", Proceedings of the Institute of Civil Engineers, Vol-44, 31-48.

[13] Vintzileou E, Yong Lu, Zhang GF (1998), "Seismic behaviour of multi-storey r/c frames tested on an earthquake simulator", Proceedings of the 6th SECED Conference on Seismic Design Practice, Booth E, A A Balkema: Rotterdam, 443-450

[14] Yogendra Singh and Dipankar Das (2006), "Effect of URM Infills on Seismic performance of RC Frame Buildings", 4th International conference on Earthquake Engineering, Taipei Taiwan, Paper No. 064

\section{Codes / Standards}

[15] European Committee of Standardization, 2003, Euro code 8: “design of Structures for Earthquake Resistance-Part 1: General Rules, Seismic Actions and Rules for Buildings", prEN 1998-1, Brussels, Belgium.

[16] Indian Standard IS 456-2000, "Plain and Reinforced Concrete-Code of Practice," BIS, New Delhi, Indian.

[17] Indian standard, IS 516-1959, "Methods of tests for strength of Concrete," BIS, New Delhi, stored materials, BIS, Manak Bhawan, New Delhi, India.

[18] Indian Standard, IS 13920-1993, "Ductile Detailing of Reinforced Concrete Structures subjected to Seismic Forces"-Code of Practice, BIS, New Delhi, India. 
Xperimental Studies On Characterising Of A seismic Performance Of Reinforced Concrete Frames

\begin{tabular}{|c|c|c|c|c|c|c|c|c|c|c|c|c|c|}
\hline Time & V. Stroke & H.Stroke & $\begin{array}{l}\text { V. Load } \\
\text {. }\end{array}$ & H. Load & 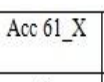 & Acc 62_X & Acc 64_X & Acc 65_X & Acc 66_X & Acc 69_X & $\begin{array}{l}\text { Gauging } \\
\text { LVDT1 } \\
\end{array}$ & $\begin{array}{l}\text { Gauging } \\
\text { LVDT2 } \\
\end{array}$ & SP-Vertical \\
\hline $\mathrm{sec}$ & $\mathrm{mm}$ & $\mathrm{mm}$ & $\mathrm{kN}$ & $\mathrm{kN}$ & $\mathrm{g}$ & $\mathrm{g}$ & $\mathrm{g}$ & $\mathrm{g}$ & $\mathrm{g}$ & $\mathrm{g}$ & & & \\
\hline 0.02 & -21760 & 0.0372 & -0.1022 & -4.2163 & 0.861 & -0.6722 & -2.4647 & -4.2768 & -0.9734 & 0.1332 & -3.2135 & -3.1227 & -21760 \\
\hline 0.03 & -21760 & 0.0373 & -0.103 & -4.2173 & 0.864 & -0.6741 & -2.4645 & -4.2766 & -0.9734 & 0.1324 & -3.215 & -3.1247 & -21760 \\
\hline 0.04 & -21760 & 0.0377 & -0.1009 & -4.222 & 0.8609 & -0.6721 & -2.4647 & -4.2768 & -0.9734 & 0.1332 & -3.2148 & -3.1226 & -21760 \\
\hline 0.05 & -21760 & 0.0377 & -0.0951 & -4.2205 & 0.8618 & -0.6739 & -2.4645 & -4.2766 & -0.9734 & 0.1324 & -3.2156 & -3.1241 & -21760 \\
\hline 0.06 & -21760 & 0.037 & -0.1013 & -4.2231 & 0.863 & -0.6743 & -2.4647 & -4.2768 & -0.9734 & 0.1332 & -3.2149 & -3.1235 & -21760 \\
\hline 0.07 & -21760 & 0.0379 & -0.0985 & -4.2198 & 0.8637 & -0.6717 & -2.4646 & -4.2766 & -0.9733 & 0.1324 & -3.2151 & -3.124 & -21760 \\
\hline 0.08 & -21760 & 0.0382 & -0.1014 & -4.2178 & 0.8627 & -0.6731 & -2.4647 & -4.2767 & -0.9734 & 0.1333 & -3.2161 & -3.1242 & -21760 \\
\hline 0.09 & -21760 & 0.0372 & -0.0976 & -4.2158 & 0.8635 & -0.6738 & -2.4646 & -4.2766 & -0.9733 & 0.1324 & -3.2156 & & \\
\hline 0.1 & -21760 & 0.0374 & -0.1012 & 4.2184 & 0.8625 & -0.6703 & -2.4647 & -4.2768 & -0.9734 & 0.1333 & -3.2157 & -3.1235 & -21760 \\
\hline 0.11 & -21760 & 0.0375 & -0.1039 & -4.2156 & 0.8606 & -0.6728 & -2.4646 & -4.2767 & -0.9733 & 0.1324 & -3.216 & -3.1239 & -21760 \\
\hline 0.12 & -21760 & 0.0375 & -0.1024 & 4.218 & 0.8634 & -0.6699 & -2.4647 & -4.2769 & -0.9734 & 0.1333 & -3.2158 & -3.1236 & -21760 \\
\hline 0.13 & -21760 & 0.0375 & -0.0987 & -4.216 & 0.8605 & -0.672 & -2.4646 & -4.2767 & -0.9733 & 0.1323 & -3.2153 & -3.1236 & -21760 \\
\hline 0.14 & -21760 & 0.0372 & -0.097 & -4.2162 & 0.8597 & -0.6722 & -2.4647 & -4.2768 & -0.9734 & 0.1333 & -3.217 & -3.1245 & -21760 \\
\hline 0.15 & -21760 & 0.0364 & -0.1026 & -4.2229 & 0.8611 & -0.6729 & -2.4646 & -4.2767 & -0.9734 & 0.1323 & -3.2156 & -3.1231 & -21760 \\
\hline 0.16 & -21760 & 0.0366 & -0.0968 & -4.2201 & 0.8627 & -0.6728 & -2.4647 & -4.2768 & -0.9734 & 0.1333 & -3.2156 & -3.1249 & -21760 \\
\hline 0.17 & -21760 & 0.0366 & -0.101 & 4.2197 & 0.8597 & -0.6733 & -2.4646 & -4.2766 & -0.9734 & 0.1323 & -3.2149 & -3.1238 & -21760 \\
\hline 0.18 & -21760 & 0.0374 & -0.1014 & -4.2127 & 0.8623 & -0.6732 & -2.4647 & -4.2768 & -0.9734 & 0.1333 & -3.2149 & -3.1236 & \\
\hline 0.19 & -21760 & 0.0372 & -0.0976 & -4.2203 & 0.8615 & -0.6693 & -2.4646 & -4.2767 & -0.9733 & 0.1323 & -3.2159 & -3.124 & \\
\hline 0.2 & -21760 & 0.037 & -0.1013 & -4.2193 & 0.8641 & -0.6744 & -2.4647 & -4.2768 & -0.9734 & 0.1333 & 3.2155 & -3.1237 & -21760 \\
\hline 0.21 & -21760 & 0.0369 & -0.1021 & -4.2197 & 0.8611 & -0.6701 & -2.4645 & -4.2767 & -0.9734 & 0.1323 & -3.2161 & -3.1231 & -21760 \\
\hline 0.22 & -21760 & 0.0373 & -0.1002 & -4.2185 & 0.8624 & -0.6734 & -2.4647 & -4.2768 & -0.9734 & 0.1334 & -3.2158 & -3.1243 & -21760 \\
\hline $0 . \dot{2} 3$ & -21700 & 0.0377 & -0.1015 & -4.2225 & 0.8636 & -0.6739 & 2.4646 & -4.2766 & -0.9734 & 0.1323 & -3.2156 & -3.1231 & -21760 \\
\hline 0.24 & -21760 & 0.0376 & -0.0984 & -4.219 & 0.8613 & -0.6733 & -2.4647 & -4.2768 & -0.9734 & 0.1333 & -3.2159 & -3.1246 & -21760 \\
\hline 0.25 & -21760 & 0.0376 & -0.0984 & -4.2165 & 0.8613 & -0.6726 & -2.4646 & -4.2767 & -0.9733 & 0.1323 & -3.2155 & -3.1241 & -21760 \\
\hline 0.26 & -21760 & 0.0366 & -0.0986 & -4.2131 & 0.8601 & -0.6676 & -2.4646 & -4.2768 & -0.9734 & 0.1332 & -3.2148 & -3.1242 & -21760 \\
\hline 0.27 & -21760 & 0.0368 & -0.1 & -4.2209 & 0.8611 & -0.6734 & -2.4646 & -4.2766 & -0.9733 & 0.1322 & -3.2145 & -3.1237 & -21760 \\
\hline 0.28 & -21760 & 0.0367 & -0.0985 & -4.2191 & 0.8615 & -0.6713 & -2.4647 & -4.2769 & -0.9734 & 0.1334 & -3.2147 & -3.124 & -2176 \\
\hline 0.29 & -21760 & 0.0371 & -0.0959 & -4.2218 & 0.8644 & -0.6719 & -2.4645 & -4.2766 & -0.9734 & 0.1322 & -3.2154 & -3.1235 & -21760 \\
\hline 0.3 & -21760 & 0.0366 & -0.1027 & -4.2198 & 0.8624 & -0.67 & -2.4647 & -4.2768 & -0.9734 & 0.1334 & -3.2156 & -3.1236 & -21760 \\
\hline 0.31 & -21760 & 0.0372 & -0.0998 & -4.2201 & 0.8623 & -0.6751 & -2.4646 & -4.2766 & -0.9733 & 0.1323 & -3.2156 & -3.1233 & -2176 \\
\hline 0.32 & -21760 & 0.0377 & -0.0974 & -4.2142 & 0.8609 & -0.6707 & -2.4647 & -4.2769 & -0.9734 & 0.1334 & -3.2151 & -3.1233 & -21760 \\
\hline 0.33 & -21760 & 0.0363 & -0.0948 & -4.2212 & 0.8647 & -0.6734 & -2.4645 & -4.2766 & -0.9734 & 0.1322 & -3.2143 & -3.1236 & -21760 \\
\hline 0.34 & -21760 & 0.0377 & -0.0951 & -4.2229 & 0.8617 & -0.6721 & -2.4647 & -4.2769 & -0.9734 & 0.1334 & -3.2149 & -3.1238 & -21760 \\
\hline 0.35 & -21760 & 0.0369 & -0.0974 & -4.2195 & 0.8604 & -0.6715 & -2.4646 & -4.2766 & -0.9734 & 0.1322 & -3.2158 & -3.123 & -2176 \\
\hline 0.36 & -21760 & 0.0365 & -0.0956 & -4.2172 & 0.8617 & -0.6722 & -2.4647 & -4.2768 & -0.9734 & 0.1334 & -3.2154 & -3.1242 & -2176 \\
\hline 0.37 & -21760 & 0.0361 & -0.0982 & -4.2219 & 0.8606 & -0.6715 & -2.4646 & -4.2766 & -0.9734 & 0.1322 & -3.2172 & -3.1232 & -21760 \\
\hline 0.38 & -21760 & 0.0369 & -0.0995 & -4.2197 & 0.8606 & -0.6719 & -2.4647 & -4.2768 & -0.9734 & 0.1334 & -3.2149 & -3.1239 & -21760 \\
\hline 0.39 & -21760 & 0.0373 & -0.1012 & -4.221 & 0.8591 & -0.6716 & -2.4645 & -4.2766 & -0.9734 & 0.1322 & -3.2152 & -3.1233 & -21760 \\
\hline 0.4 & -21760 & 0.0367 & -0.1063 & -4.2181 & 0.8607 & -0.6721 & -2.4647 & -4.2768 & -0.9734 & 0.1334 & -3.2163 & -3.1231 & -21760 \\
\hline 0.41 & -21760 & 0.0368 & -0.1015 & -4.2206 & 0.8619 & -0.6725 & -2.4645 & -4.2766 & -0.9733 & 0.1322 & -3.2152 & -3.1245 & -2176 \\
\hline 0.42 & -21760 & 0.0368 & -0.0995 & -4.2188 & 0.8635 & -0.6738 & -2.4647 & -4.2768 & -0.9734 & 0.1334 & -3.2169 & -3.1238 & -21760 \\
\hline 0.43 & -21760 & 0.0371 & -0.0992 & -4.2216 & 0.8624 & -0.6724 & -2.4645 & -4.2766 & -0.9734 & 0.1322 & -3.2158 & -3.1242 & -21760 \\
\hline 0.44 & -21760 & 0.037 & -0.0992 & -4.212 & 0.8597 & -0.6726 & $\begin{array}{l}-2.4647 \\
\end{array}$ & -4.2767 & -0.9734 & 0.1334 & -3.2159 & -3.1233 & -21760 \\
\hline 0.45 & -21760 & 368 & -0.0992 & -4.2191 & 0.8616 & -0.6723 & -2.4646 & -4.2767 & -0.9734 & 0.1322 & -3.2158 & -3.1236 & -2176 \\
\hline 0.46 & -21760 & 0.0371 & -0.0996 & -4.2166 & 0.8625 & -0.6732 & -2.4647 & -4.2768 & -0.9734 & 0.1334 & -3.2158 & -3.1232 & -21760 \\
\hline 0.47 & -21760 & 0.0366 & -0.0991 & -4.2205 & 0.8606 & -0.6722 & -2.4645 & -4.2766 & -0.9734 & 0.1322 & -3.215 & -3.1227 & -21760 \\
\hline 0.47 & -21760 & 0.0366 & -0.0991 & 4.2205 & 0.8606 & -0.6722 & -2.4645 & -4.2766 & -0.9734 & 0.1322 & -3.215 & -3.1227 & -21760 \\
\hline 0.48 & -21760 & 0.0373 & -0.1008 & -4.2194 & 0.8614 & -0.6728 & -2.4646 & -4.2768 & -0.9735 & 0.1334 & -3.2162 & -3.1233 & -21760 \\
\hline 0.49 & -21760 & 0.0369 & -0.1004 & -4.2215 & 0.8605 & -0.6739 & -2.4645 & -4.2767 & -0.9734 & 0.1322 & -3.2153 & -3.1242 & -21760 \\
\hline 0.5 & -21760 & 0.0368 & -0.0995 & -4.2226 & 0.8634 & -0.6707 & -2.4647 & -4.2768 & -0.9735 & 0.1334 & -3.2147 & -3.1233 & -21760 \\
\hline 0.51 & -21760 & 0.0367 & -0.0993 & -4.2205 & 0.8624 & -0.6728 & -2.4645 & -4.2767 & -0.9734 & 0.1322 & $\begin{array}{r}-3.2149 \\
\end{array}$ & -3.1227 & -21760 \\
\hline 0.52 & -21760 & 0.037 & $\begin{array}{r}-0.1001 \\
\end{array}$ & -4.2182 & 0.8612 & -0.6736 & -2.4646 & -4.2768 & -0.9734 & 0.1334 & -3.2142 & -3.1233 & -21760 \\
\hline 0.53 & -21760 & 0.0373 & $\begin{array}{r}-0.1033 \\
\end{array}$ & -4.2233 & 0.8624 & -0.6726 & -2.4646 & -4.2767 & -0.9734 & 0.1322 & -3.2156 & -3.1241 & -21760 \\
\hline 0.54 & -21760 & 0.0373 & -0.1005 & -4.2163 & 0.8615 & -0.6695 & -2.4646 & -4.2768 & -0.9735 & 0.1334 & -3.2155 & -3.1223 & -21760 \\
\hline 0.55 & -21760 & 0.0368 & -0.0977 & -4.2229 & 0.862 & -0.6721 & -2.4646 & -4.2766 & -0.9734 & 0.1322 & -3.2156 & -3.1227 & -21760 \\
\hline
\end{tabular}


Xperimental Studies On Characterising Of A seismic Performance Of Reinforced Concrete Frames

\begin{tabular}{|c|c|c|c|c|c|c|c|c|c|c|c|c|c|}
\hline 0.56 & 21760 & 0.0364 & -0.0991 & -4.2142 & 0.8613 & $\begin{array}{l}-0.6731 \\
\end{array}$ & -2.4647 & -4.2768 & -0.9734 & 0.1333 & -3.2149 & -3.1233 & -21760 \\
\hline 0.57 & 21760 & 0.0363 & -0.1033 & -4.2162 & 0.8607 & -0.6729 & -2.4646 & -4.2766 & -0.9734 & 0.1322 & -3.2138 & -3.1235 & -21760 \\
\hline 0.58 & 21760 & 0.0366 & -0.1 & -4.2146 & 0.862 & -0.6701 & -2.4647 & 4.2768 & -0.9734 & 0.1333 & -3.2148 & -3.1233 & -21760 \\
\hline 0.59 & -21760 & 0.0362 & -0.0997 & 4.2168 & 0.8619 & -0.6721 & -2.4646 & 4.2766 & -0.9734 & 0.1322 & -3.2154 & -3.1231 & 21760 \\
\hline 0.6 & -21760 & 0.0368 & -0.103 & 4.2192 & 0.8629 & -0.6717 & -2.4646 & 4.2768 & -0.9734 & 0.1334 & -3.2147 & -3.1233 & -21760 \\
\hline 0.61 & -21760 & 0.037 & -0.0993 & -4.2198 & 0.8632 & -0.6723 & -2.4646 & -4.2767 & -0.9734 & 0.1323 & -3.2142 & -3.1228 & -21760 \\
\hline 0.62 & -21760 & 0.0368 & -0.1021 & -4.2187 & 0.8634 & -0.6717 & -2.4646 & -4.2768 & -0.9734 & 0.1334 & -3.2156 & -3.1226 & -21760 \\
\hline 0.63 & -21760 & 0.0371 & -0.1046 & -4.2192 & 0.8623 & -0.6785 & -2.4646 & -4.2767 & -0.9734 & 0.1323 & -3.2146 & -3.1239 & 21760 \\
\hline 0.64 & -21760 & 0.0368 & -0.102 & -4.2263 & 0.8624 & -0.6714 & -2.4647 & -4.2768 & -0.9734 & 0.1333 & -3.2151 & -3.1228 & -21760 \\
\hline 0.65 & -21760 & 0.0364 & -0.1033 & 4.2213 & 0.864 & -0.6533 & -2.4646 & 4.2767 & -0.9734 & 0.1323 & -3.2188 & -3.1231 & -21760 \\
\hline 0.66 & -21760 & 0.037 & -0.1053 & 4.2019 & 0.86 & -0.6829 & -2.4647 & 4.2768 & -0.9734 & 0.1333 & -3.2121 & -3.1231 & -21760 \\
\hline 0.67 & -21760 & 0.0369 & -0.1059 & -4.2248 & 0.8606 & -0.6744 & -2.4646 & -4.2767 & -0.9734 & 0.1323 & -3.2138 & -3.1235 & -21760 \\
\hline 0.68 & -21760 & 0.037 & -0.0986 & -4.2203 & 0.8609 & -0.6682 & -2.4646 & -4.2768 & -0.9734 & 0.1333 & -3.2186 & -3.1245 & -21760 \\
\hline 0.69 & -21760 & 0.0377 & -0.1021 & 4.2047 & 0.8572 & -0.6796 & -2.4646 & -4.2767 & -0.9733 & 0.1323 & -3.2137 & -3.1236 & -21760 \\
\hline 0.7 & -21760 & 0.0383 & -0.1035 & 4.21 & 0.8642 & $\begin{array}{l}-0.6732 \\
\end{array}$ & -2.4646 & -4.2768 & -0.9734 & 0.1332 & -3.2168 & -3.124 & -21760 \\
\hline 0.71 & -21760 & 0.0379 & -0.1019 & -4.2344 & 0.8636 & -0.673 & -2.4646 & -4.2767 & -0.9734 & 0.1323 & -3.2162 & -3.1245 & -21760 \\
\hline 0.72 & -21760 & 0.0379 & -0.1043 & -4.223 & 0.8647 & -0.6797 & -2.4647 & -4.2767 & -0.9734 & 0.1332 & -3.2136 & -3.1242 & -21760 \\
\hline 0.73 & -21760 & 0.0386 & -0.1015 & -4.2187 & 0.8624 & -0.657 & -2.4646 & -4.2766 & -0.9733 & 0.1323 & -3.2159 & -3.124 & -21760 \\
\hline 0.74 & -21760 & 0.0386 & -0.1014 & -4.2097 & 0.8614 & -0.6739 & -2.4646 & -4.2768 & -0.9735 & 0.1333 & -3.2162 & -3.1241 & -21760 \\
\hline
\end{tabular}

